Review

\title{
Biomaterial Implants in Abdominal Wall Hernia Repair: A Review on the Importance of the Peritoneal Interface
}

\author{
Verónica Gómez-Gil 1,2,*, Gemma Pascual ${ }^{2,3,4}$ [1] and Juan M. Bellón 1,2,4 \\ 1 Department of Surgery, Medical and Social Sciences, Faculty of Medicine and Health Sciences, \\ University of Alcalá, C.P: 28871 Alcalá de Henares, Madrid, Spain; juanm.bellon@uah.es \\ 2 Networking Biomedical Research Centre on Bioengineering, Biomaterials and Nanomedicine (CIBER-BBN), \\ 50001 Zaragoza, Spain; gemma.pascual@uah.es \\ 3 Department of Medicine and Medical Specialties, Faculty of Medicine and Health Sciences, \\ University of Alcalá, C.P: 28871 Alcalá de Henares, Madrid, Spain \\ 4 Ramón y Cajal Health Research Institute (IRYCIS), C.P: 28034 Madrid, Spain \\ * Correspondence: veronica.gomezg@uah.es; Tel.: +34-918852585
}

Received: 1 January 2019; Accepted: 10 February 2019; Published: 16 February 2019

\begin{abstract}
Biomaterials have long been used to repair defects in the clinical setting, which has led to the development of a wide variety of new materials tailored to specific therapeutic purposes. The efficiency in the repair of the defect and the safety of the different materials employed are determined not only by the nature and structure of their components, but also by the anatomical site where they will be located. Biomaterial implantation into the abdominal cavity in the form of a surgical mesh, such as in the case of abdominal hernia repair, involves the contact between the foreign material and the peritoneum. This review summarizes the different biomaterials currently available in hernia mesh repair and provides insights into a series of peculiarities that must be addressed when designing the optimal mesh to be used in this interface.
\end{abstract}

Keywords: surgical mesh; hernia repair; peritoneum; peritoneal adhesions; omentum; polypropylene; hernia recurrence; abdominal wall

\section{Introduction}

Biomaterials are being extensively used as scaffolds in the field of tissue engineering and reparative medicine. The term biomaterial defines a biological or synthetic material whose aim is to contribute to the repair or regeneration of a damaged tissue by its partial or total replacement [1]. For this reason, biomaterials find their widest range of application in surgical procedures, their design determined by the specific function for which they are intended.

The promising results that they provide in the repair of tissue defects have led to a spectacular increase of their use in current clinical practice, which has in turn contributed to the development and evolution of the surgical techniques performed in different medical specialties. Biomaterials turn out to be vital in solving important functional conditions such as orthopedic, vascular or ophthalmologic-related medical issues, among others. Thereby, an improvement in the patients' quality of life due to biomaterials is not only positive from a clinical perspective, but also through the contribution to their psychological well-being.

The complexity of biomaterials and the great responsibility that their use implies requires that their design and development take up a multidisciplinary approach. Thus, the involvement of professionals from different fields (e.g., chemists, biologists, engineers, histopathologists and surgeons) is essential to achieve the expected outcomes that would benefit patients suffering from different pathologies. 
One of the most frequent surgical application of biomaterials in recent years has been hernia repair. Every year around twenty million hernia repair procedures are performed around the world [2]. Inguinal hernia repair is the surgical procedure most often conducted by general surgeons [3]. The use of biomaterials for this purpose in the form of surgical meshes has drastically contributed to a decrease in the hernia recurrence rate [4], which is one of the most common complications that occur in patients undergoing this type of surgery.

\section{Biomaterials in Abdominal Wall Repair}

The repair of the abdominal wall is commonly required in the event of abdominal hernias or open wounds. Abdominal hernias require surgical intervention since they cause pain or discomfort and, more importantly, can produce the protrusion of intraabdominal organs through these defects, which could cause tissue strangulation. The incidence of ventral hernias is high; nearly 350,000 repairs are performed each year in the United States [5].

Abdominal wall reconstruction is a complex procedure that seeks to restore the abdominal wall structure by maintaining its natural strength and elasticity as much as possible while causing the least side effects. The traditional repair methods consisted of primary closure by open suture techniques. However, these techniques are no longer recommended since they are related to high recurrence and wound dehiscence rates [6,7] that could eventually lead to evisceration, especially in the event of large defects [7]. The placement of mesh as an alternative technique in abdominal wall repair offers some advantages over the suture closure [8]. Meshes confer an extra surface, avoiding the surgical approximation of the defect edges and the subsequent excessive tension in the area. This tension would be responsible for impaired tissue healing, tissue ischemia, and defective closure or reconstruction of the wall, that could result in wound dehiscence and herniation [6]. However, although superior to traditional suture closure, the use of meshes is not without complications. This underlies the complexity of the processes carried out during abdominal wall reconstruction and the large amount of factors involved.

The improved outcomes achieved by the use of surgical meshes have triggered the development of different biomaterials to be used in the abdominal location. Research on abdominal meshes has been traditionally based on comparative analyses of materials with different chemical or biological nature and/or the optimization of their physical and mechanical properties. Different reviews on the different biomaterials available from the point of view of their composition, bio-functionality or their structural and mechanical properties have been previously published [9-13]. In this review, we have specifically focused on their behavior at the peritoneal interface. The still high incidence of postsurgical peritoneal adhesions after intraperitoneal mesh implantation and the severe clinical complications that result make necessary a comprehensive understanding of the most relevant factors implied. Here, we provide a review on the abdominal cavity contents involved in adhesion formation, the host tissue, and cell response exerted by biomaterials in this cavity and the adhesiogenic process. An updated classification of biomaterials available for abdominal surgery is presented, targeting principally their performance in relation to adhesion formation.

\section{Mesh Positioning in the Abdominal Wall}

According to the position relative to the peritoneum, meshes can be implanted: extraperitoneally i.e., in a retromuscular plane and not in direct contact with the bowels; or intraperitoneally, between the peritoneum and the intraabdominal organs and bowels. In both alternatives, complications can arise. However, the intraperitoneal position poses an increased risk of dangerous events such as mesh migration [14-19], adhesions [20,21], intestinal obstruction [15,19] or fistulae [16,20-24], that can occur even several years after the mesh placement. Notwithstanding, the IPOM (intraperitoneal onlay mesh) technique is indicated in several patients who have undergone a previous laparoscopic repair, an infraumbilical surgery with violation of the preperitoneal space, or suffer from a recurrent inguinal hernia [25]. 


\section{The Abdominal Cavity}

The success of a biomaterial implant in the abdominal cavity is conditioned by the resolution of different processes characteristic of this anatomical site. The damage to intraabdominal tissues/organs like the peritoneum or the omentum provokes a specific cell and tissue response.

\subsection{The Peritoneum}

A key factor in the intraabdominal mesh implantation is the contact between the biomaterial and the peritoneum. The peritoneum is a serous membrane that consists of a basal lamina and a submesothelial stroma covered by a mesothelial cell monolayer [26]. This membrane covers the inner side of the abdominopelvic cavity-defined as parietal peritoneum — as well as the surface of the intraabdominal structures, known as visceral peritoneum. The contact of a biomaterial with the parietal and visceral peritoneum — when in the intraperitoneal position—or just with the visceral peritoneum —in total defects hernia repair which include the removal of the parietal peritoneum-requires some special considerations to be made when selecting the most appropriate mesh to be used. The peritoneum can be easily harmed during abdominal surgery. The first layer exposed in peritoneum is the mesothelium, which is a delicate structure. At the intercellular junctions in the mesothelium some openings—stomata-that provide direct access to the submesothelial lymphatic system are found $[27,28]$. This makes this layer highly permeable to the peritoneal fluid. Mesothelial cells (MCs) present numerous microvilli at their apical membrane surrounded by a lubricating glycocalyx [28]. This glycocalyx has an anti-inflammatory function and plays an important role in intercellular contacts and tissue remodeling $[28,29]$. Thus, the mesothelial layer confers a protective cover for the underlying tissue. MCs are supported by the basal lamina through weak bindings, which indicates that these cells can be easily detached in case of mechanical insult [30]. Considering the slight thickness of the basal lamina, less than $100 \mathrm{~nm}$ thick [26], when the peritoneum is injured during intraabdominal procedures, both the mesothelial monolayer and the basal lamina are usually removed leaving the submesothelial stroma underneath exposed. Besides collagen type I fibers, laminin, fibronectin, proteoglycans and glycosaminoglycans, also fibroblasts, adipocytes, nerves, blood and lymphatic vessels can be found in this layer [31]. The exposure of these cell types and components after trauma is of importance for the reparation of the zone and has an influence on the adhesion formation process [32]. In addition to disruption of the mesothelial layer, the mechanical injury and the peritoneal inflammation produce the release of cytokines and growth factors, such as TGF- $\beta$ (transforming growth factor- $\beta$ ) [33], that provokes the epithelial-to-mesenchymal transition of MCs [34-36]. This process plays a pivotal role in peritoneal fibrosis through the conversion of MCs into migratory and invasive cells with a myofibroblastic phenotype [37,38]. These cells secrete-among other growth factors-VEGF (vascular endothelial growth factor), which is an inductor of angiogenesis [39,40]. Reparative macrophages also promote neoangiogenesis and release growth factors and matrix-remodeling enzymes [41]. These events, together with the release of other proangiogenic factors like b-FGF (basic fibroblastic growth factor) [42], can contribute to the stabilization of peritoneal adhesions as permanent structures between the biomaterial and the opposing intraabdominal organs.

\subsection{The Omentum}

The omentum is a highly vascularized tissue that lies posterior to the abdominal wall and serves as coverage and protection for the intraabdominal contents [43]. It is of greatest importance in adhesion formation, since it is involved in $92 \%$ of postsurgical adhesions and in $100 \%$ of spontaneous adhesions [44]. It exhibits a particular predisposition to attach to foreign materials like surgical meshes in the abdominal cavity $[45,46]$, which is probably due to its particular cell composition that provides this tissue with an immunologic role [47,48] and tissue remodeling properties [43]. It is mainly composed of white adipose tissue in a lobular configuration septated by connective tissue and delineated by a mesothelial layer. It contains abundant blood and lymphatic vessels, especially in 
the submesothelial layer, and lymphoid bodies, so-called milky spots, in the outermost layer of the omentum or embedded in the adipose tissue [49]. The existence of this organ in the abdominal cavity largely conditions the host tissue response to a biomaterial implant in this location. The omentum shows a rapid response to abdominal injury, with the mobilization of cells comprising the milky spots that proliferate and spread over the omental tissue [49] and secrete growth factors and cytokines related to tissue repair and remodeling [43,49]. MCs (especially those near milky spots) have shown changes in their phenotype in response to injury, returning to normality only after tissue repair [50]. Besides, fibrocytes, pericytes and fibroblasts contained in the omentum provide an environment that supports tissue growth via angiogenic factors and cytokines that promote wound closure, vascular development and remodeling as well as collagen deposition [43]. A different progression of the omental tissue involved in adhesions to an adipose or fibrotic phenotype has been observed and correlated to the presence of different isoforms of TGF- $\beta$ (TGF- $\beta 1$ and TGF- $\beta 3$ ) and the concomitant expression of the soluble or the membrane-bound form of betaglycan (type III TGF- $\beta$ receptor) [49]. A similar role for the different isoforms of TGF- $\beta$ and their receptors in the response of peritoneum to abdominal injury is still to be investigated.

Bearing all this in mind, it seems clear that the abdominal cavity represents an anatomical location with particular features that need to be considered when designing or selecting the mesh to be employed in order to minimize adverse medical outcomes.

\subsection{Host Tissue and Cell Response}

The presence of a foreign material into the abdominal cavity triggers a series of events influenced by the individual response of the patient and the surgical procedure performed. As part of the reparative process, an inflammatory response is exerted in an attempt to contribute to the restoration of the damaged area and to encapsulate the foreign biomaterial to separate it from the surrounding tissue [51]. The normal course of the reparative process requires a perfect orchestration of all the phases-hemostasis, inflammation, proliferation and remodeling — and every cell type involved. For this reason, the understanding of the events and signaling processes occurred during wound healing, and specifically in the presence of a foreign material, is crucial in abdominal wall repair.

After peritoneal injury during a surgical procedure or mediated by the subsequent mechanical aggression of the implanted mesh, different substances like histamine or vasoactive quinines are released. Thereby, the permeability of the blood vessels is favored. A protein fibrinous exudate covers the damaged area (Figure 1) and is infiltrated by inflammatory cells. The first cell type attracted by chemokines that appear in the damaged area are polymorphonuclear neutrophils, which contribute to the ingestion of foreign particles or microorganisms. The following important event in the inflammatory phase is the appearance of monocytes that are attracted by the pro-inflammatory cytokines IL (interleukin) - 1 , IL-6, IL-8, and TNF- $\alpha$ (tumor necrosis factor alpha) released in the peritoneal fluid [52]. Monocytes differentiate into macrophages once in the tissue and adhere to the wound. There, they will release numerous cytokines that constitute the real effectors of the phagocytic defense system. Adherent macrophages attempt to phagocyte the biomaterial and fuse to form foreign body giant cells in a biomaterial-dependent process [51]. Macrophages can also prevent during the first $48 \mathrm{~h}$ and then stimulate from 48 to $54 \mathrm{~h}$ after damage the MCs proliferation. Also, MCs release different cytokines and growth factors to the peritoneal fluid to mediate the peritoneal healing. Two macrophage subpopulations are involved in the post-implantation response. M1 macrophages favor inflammatory reaction, while the M2 subpopulation has a role in tissue remodeling. Leukocytes in the early phases also promote the proliferation of the normally quiescent MCs [52]. Lymphocytes type T have been found in the macrophage infiltrates, developing the immune response. The secretory products of macrophages modulate the fibroblasts proliferation during the proliferative phase. Under the action of TGF- $\beta$, quiescent fibroblasts differentiate into myofibroblasts [51], a cell type that exerts an essential role into the reparative process by synthesizing collagen and restoring the extracellular matrix. Lately, type III collagen fibers are replaced by type I collagen during the remodeling phase. 
Fibrillar collagens provide the support and tensile strength that give the extracellular matrix its structural integrity. The third day after the lesion to the peritoneum, MCs cover the peritoneal macrophages present in the damaged area and proliferate during the following days, forming multiple cell islets. The confluence of these islets leads to the restoration of the mesothelium (Figure 1) which, as previously mentioned, represents the protective cover of the peritoneum and eventually the abdominal cavity. The neoperitoneum promotes fibrinolysis through the release of tissue-type (tPA) and urokinase-type (uPA) plasminogen activator (Figure 1), together with the inhibition of cell-cell and cell-tissue interactions through the release of hyaluronic acid from the MCs [53]. In this intricate and time-organized process, any imbalance or mismatch in the healing events or in the function of the cells involved due to the presence or degradation of the biomaterial could produce unexpected responses of the host tissue that could result in clinical complications.

\section{Peritoneal Adhesions}

Adhesiogenesis is the most common cause of long-term complications observed after abdominopelvic surgery [54], leading to serious consequences such as bowel obstruction, or chronic abdominal pain or infertility in women undergoing a gynaecological procedure [55,56]. In fact, 80-90\% of patients develop adhesions after intraabdominal surgery [54,57], especially after surgical mesh implantation. Adhesions are responsible for the majority of bowel obstructions in the Western world [58]. For these reasons, postoperative adhesions remain one of the most challenging issues in surgical practice [59-61].

Adhesions are pathologic bands connecting adjacent structures [59]. Under normal conditions, the blood clot and the fibrinous connections formed after trauma to the peritoneal interface are lysed within a few days by fibrinolytic substances, resulting in the repair of the damaged area [32]. Inflammation at the site of injury can inhibit or delay this fibrinolytic activity through the release of plasminogen activator inhibitors (PAI-1 and PAI-2), leading to persistent fibrin deposits that become an insoluble network on which cells can migrate and proliferate [32,52] (Figure 1). This situation produces permanent connections of fibrous tissue between two previously unrelated surfaces [59,62], giving rise to adverse complications of varying severity [56]. Different types of adhesions have been observed, leading to different classifications [63-67]. A correlation between the macroscopic and/or microscopic characteristics—such as the resistance to traction, thickness, tissue composition or the degree of the vascularization of the adhesion-and the severity and clinical significance of adhesions can be established. Thus, loose adhesions, usually corresponding to an adipose or fibrinous content, are poorly vascularized, easily dissected, and do not lead to very serious complications. On the contrary, a fibrotic phenotype corresponding to firm—vascularized and difficult to dissect-or integrated adhesions that are highly vascularized and require sharp dissection, occasionally produce serosal damage of the organ involved, which can produce incarceration of intraabdominal organs and eventual bowel obstruction and enterocutaneous fistulae. Thus, the extent and clinical severity of the adhesions formed after the placement of a surgical mesh into the abdominal wall are highly influenced by the performance of the surgical procedure itself and the degree of peritoneal injury and inflammation that the specific biomaterial triggers. The required features for the most suitable biomaterial in this regard are still to be unequivocally established, while the individual response of the patient seems to play a crucial role. 


\section{Intraperitoneal onlay mesh repair}
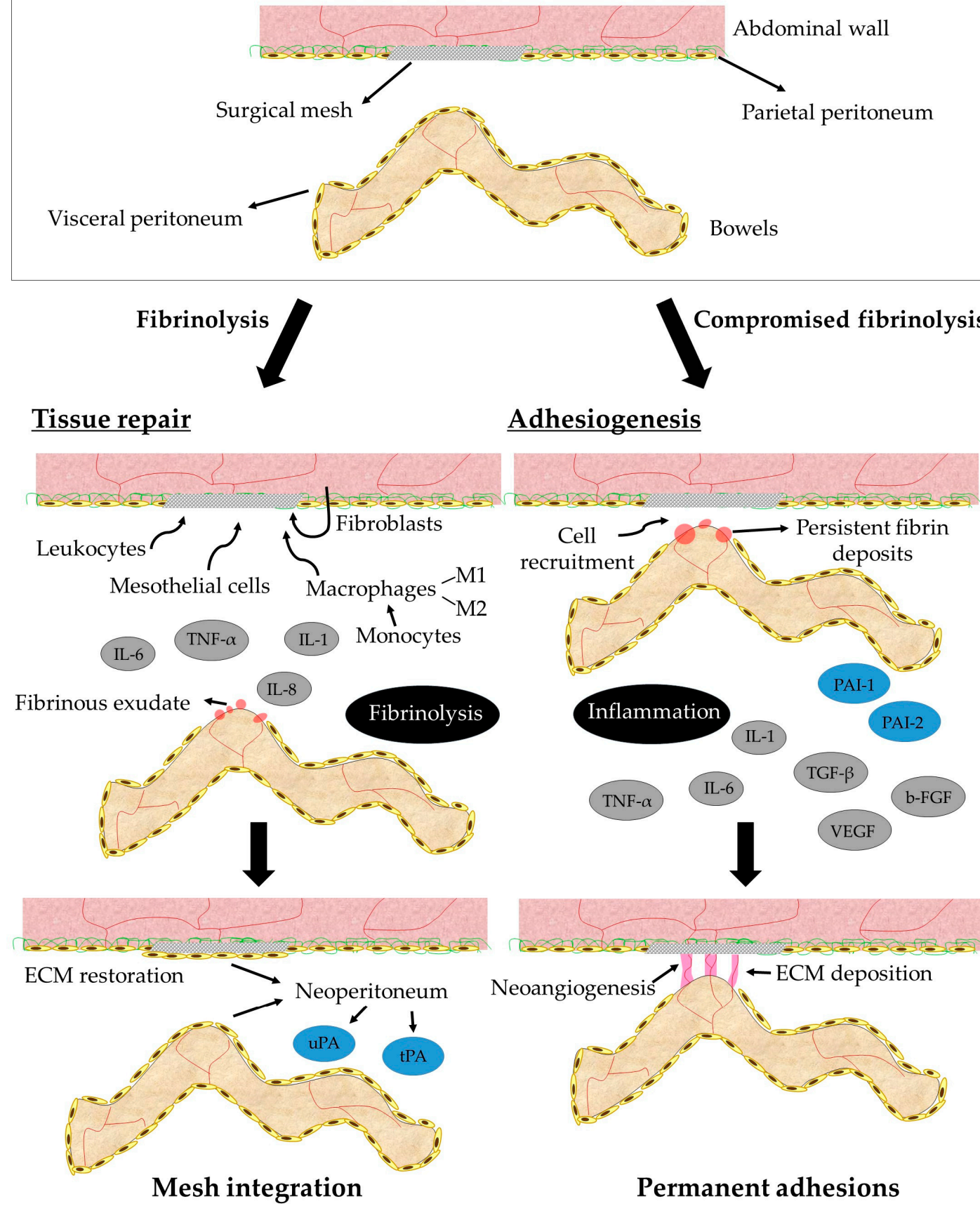

Adhesiogenesis
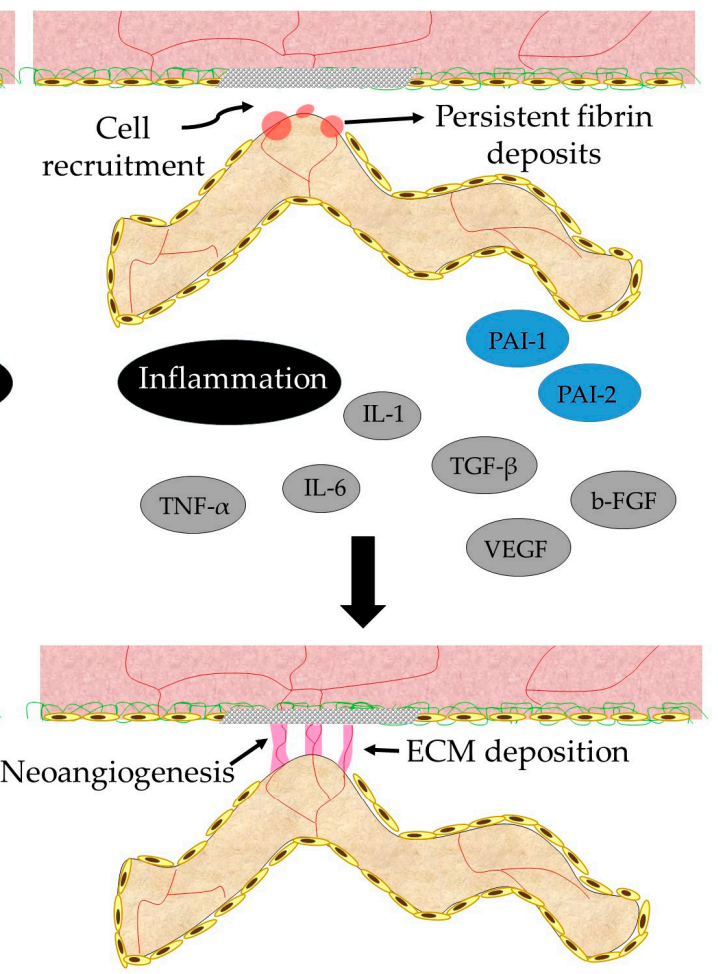

Permanent adhesions

Figure 1. Diagram showing the two possible pathways after peritoneal injury during intraperitoneal onlay mesh repair. The presence of a mesh into the abdominal cavity produces an inflammatory response and the appearance of a fibrinous exudate in the damaged areas. Under normal circumstances (left panel), the fibrinolytic system degrades fibrin and a neoperitoneum is formed, leading to tissue repair and mesh integration. If fibrinolysis is inhibited or delayed (right panel), fibrin deposits persist and permanent tissue connections (adhesions) are established between opposing surfaces. ECM, extracellular matrix.

\section{Available Biomaterials for Abdominal Surgery}

The difficulty in finding the proper equilibrium between the intended clinical effect and avoidance of collateral damage has resulted in a significant evolution in the number and types of prosthetic 
materials available for abdominal wall reconstruction. Currently, nearly 150 options for prosthetic materials with varying composition, weight, cost, and indications for use in the surgical field are available to the general surgeon [68,69], with the ongoing development of new additional meshes [9]. An in-depth knowledge of the advantages and disadvantages of the diverse materials currently available is needed when selecting the optimal mesh according to a specific situation.

\subsection{Synthetic Meshes}

\subsubsection{Permanent Reticular Materials}

After the use of high-density polyethylene fiber (Marlex®) as the first synthetic mesh [70], polypropylene (PP) started to be used since it offered a more malleable and heat-resistant option that could be autoclaved [71]. Nowadays, PP still constitutes the most employed material in the abdominal location [10] even if other materials such as polyester (PS) were introduced [72]. Since these materials usually present a reticular disposition of the filaments (Figure 2), the damage to the peritoneum is a common event that gives rise to high adhesion formation rates. Infection is also a common adverse event in the use of synthetic materials [73]. Besides, PP shows shrinkage rates of $30-50 \%$ at 4 -weeks, which could be responsible for secondary postimplantation folding in cases of poor elasticity and small pores [74]. Thus, the use of reticular meshes is discouraged in the intraperitoneal position. While the behavior at the biomaterial/parietal peritoneum interface is satisfactory (proper host tissue integration), several adverse complications can be found at the biomaterial/visceral peritoneum interface. Different modifications such as increasing the pore size (Figure 2) or coating the mesh with a second component have been developed to avoid these complications, with different results. The proper mesothelialization on the visceral side of the biomaterial is crucial since it enables a free of micro-traumas movement of the intraabdominal organs in contact with the mesh. Reticular materials have shown a delay in mesothelial reparation, which favors the appearance and permanence of fibrin deposits that constitute the scaffold for peritoneal adhesions.

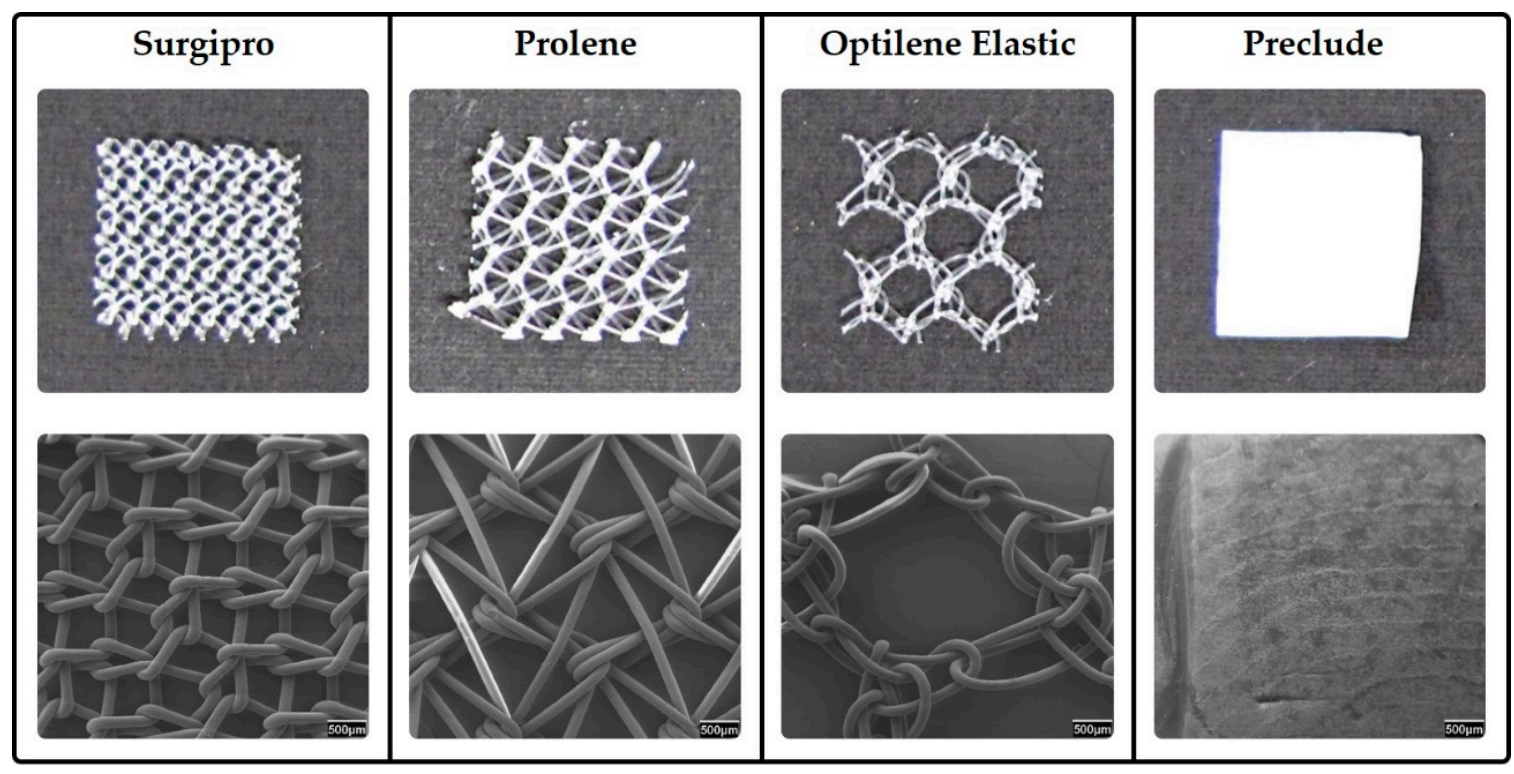

Figure 2. Permanent synthetic meshes. Reticular PP meshes with different pore sizes (Surgipro ${ }^{\mathrm{TM}}$, Prolene ${ }^{\circledR}$ and Optilene ${ }^{\circledR E}$ Elastic) and the laminar expanded polytetrafluorethylene (ePTFE) mesh (Preclude ${ }^{\circledR}$ ) are shown. Macroscopic appearance is shown in the upper images. Scanning electron micrographs show a magnified view of the meshes structure in the lower images (20x magnification). 


\subsubsection{Permanent Laminar Materials}

Polypropylene and polyester remained the two dominant mesh options until 1985, when expanded polytetrafluorethylene (ePTFE) emerged as an option, with some initial reports of improvement in adhesion formation [75]. ePTFE is a laminar microporous material (Figure 2), which induces less damage in the intraabdominal organs and creates less adhesions [76]. Mesothelialization of the laminar meshes is much better and faster than in reticular structures [77]. A reduced inflammatory foreign reaction has also been noticed in laminar PTFE compared to PP filaments. Notwithstanding, although smaller pores show an advantage in adhesion prevention, they prevent tissue in-growth and therefore integration into the host tissue [78]. Also, higher rates of infection are shown in laminar meshes that can lead to its removal [79]. When a reticular prosthesis composed of ePTFE suture thread is implanted, the adhesion incidence significantly increases compared to a laminar ePTFE [80]. This indicates that it is the spatial structure of a biomaterial that modulates the behavior at the peritoneal interface, and that the composition of the material has a lower influence. The influence of structural features has also shown to be crucial on mesh mechanical behavior in relation to the abdominal wall biomechanics [10]. Different modifications have been included in PTFE meshes to improve tissue ingrowth, giving rise to products like MycroMesh ${ }^{\circledR}$, DualMesh ${ }^{\circledR}$ or MotifMESH ${ }^{\mathrm{TM}}$ [81]. It is difficult to make any definitive statements about the clinical effectiveness of these meshes since clinical trials are not performed under identical conditions [82] and have shown very disparate results regarding adhesion formation [83,84].

\subsubsection{Composites}

Since reticular meshes offer proper host tissue integration that cannot be reached by laminar materials and laminar materials confer prevention against the adhesion formation frequently found with reticular meshes, composites were developed as the logical step in the evolution of materials to be used in abdominal wall hernia repair. Composites consist of the combination of two different components linked together whether by suturing, heat-sealing, vacuum pressing or polymer adhesion. They include a reticular mesh facing the abdominal wall with the aim to integrate into and reinforce the abdominal tissue. The second component is a laminar material facing the inner cavity that provides a smooth surface and avoids damage to the intraabdominal organs, allowing MC colonization to ensure an adequate contact with the visceral peritoneum. Thus, they acquire a bi- or multi-layered configuration that requires a careful handling to obtain the proper implantation of the device. While the reticular component on the parietal side is usually based on a permanent synthetic material, the layer facing the visceral peritoneum can take the form of a physical or chemical barrier [85]. Physical barriers consist of a nondegradable material, while chemical barriers are based on resorbable components or chemical solutions. In both cases, the laminar barrier must induce a minimal inflammatory response, allow a proper mesothelialization, and enhance neoperitoneal formation. The presence of a neoperitoneum in the visceral side of the mesh prevents the contact between the foreign material and adjacent organs and hence, avoids adhesiogenesis.

Some of these composites include added components as adhesion barriers or antimicrobial layers from a synthetic or biological origin. Among composite meshes with physical barriers, the combination of PP with ePTFE (Composix ${ }^{\mathrm{TM}}$ ) or PP with polyurethane (Combimesh Plus) can be found. Some of the composites containing chemical barriers include the following combinations: PP with omega-3 fatty acids (C-Qur); PP with polyglycolic acid and hydrogel (Ventralight ${ }^{\mathrm{TM}}$ ); PP with a film made of collagen, polyethylene glycol and glycerol (Parietene ${ }^{\mathrm{TM}}$ Composite); PP with an absorbable barrier of polydioxanone and oxidized regenerated cellulose (Proceed ${ }^{\circledR}$ ); PP with sodium hyaluronate and carboxymethylcellulose (Seprafilm ${ }^{\circledR}$ ); PP and polydioxanone fibres with an absorbable poliglecaprone 25 film (Physiomesh ${ }^{\mathrm{TM}}$ ); PS with a type I collagen, polyethylene glycol and glycerol layer (Parietex ${ }^{\mathrm{TM}}$ Composite) (Figure 3); or a fully resorbable poly-4-hydroxybutyrate (P4HB) mesh combined with a hydrogel barrier (Phasix ${ }^{\mathrm{TM}}$ ST Mesh) (Figure 3) [82,86-88], among others. In clinical studies, composite devices have been associated with lower infection, lower recurrence rates and comparable hospital stays [78]. However, the use of PTFE alone has shown better results in relation to visceral peritoneum 
than these composites [53]. Moreover, there is evidence that most of the composites prevent adhesion formation just in the short term and that the effect is diminished after 30 days [86]. The separation of the layers integrating the composite or adhesion to the bowels are also undesired events observed with these devices [89]. Despite some possible complications after the use of composites, these materials have shown an appropriate behavior at different interfaces. Adhesion formation is minimal and usually restricted to the mesh margins. An important finding is that, in the event that adhesiogenesis occurs after a composite implantation, adhesions tenacity is lower, with a tendency to the loose type $[82,90,91]$. Loose adhesions pose less serious complications than firm or integrated adhesions since the movement of adhered organs is not so restricted. Furthermore, when a chemical barrier is employed, the sequential absorption of this layer could theoretically provoke the release of the tissue adhered to it while reducing the presence of foreign residues into the host.

The combination of a permanent synthetic mesh and a biological graft — defined as hybrid mesh in the sense of bringing together materials from different nature-has also been considered, producing a device called Zenapro ${ }^{\mathrm{TM}}$. It consists of a large pore, lightweight PP mesh sandwiched between layers of extracellular matrix of porcine small intestinal submucosa (SIS). A multicenter study has been recently published [92], in which acceptable short-term outcomes and recurrence rates for Zenapro in low and medium-risk patients with clean wounds out to 12 months are shown. However, further clinical trials to determine long-term outcomes and complications with these devices [9,92] as well as to elucidate the performance at the peritoneal level are needed. In summary, composites represent a valid solution for intraperitoneal implantation, since they can provide proper tissue integration, adequate performance at the peritoneal level and good postimplantation mechanical resistance.

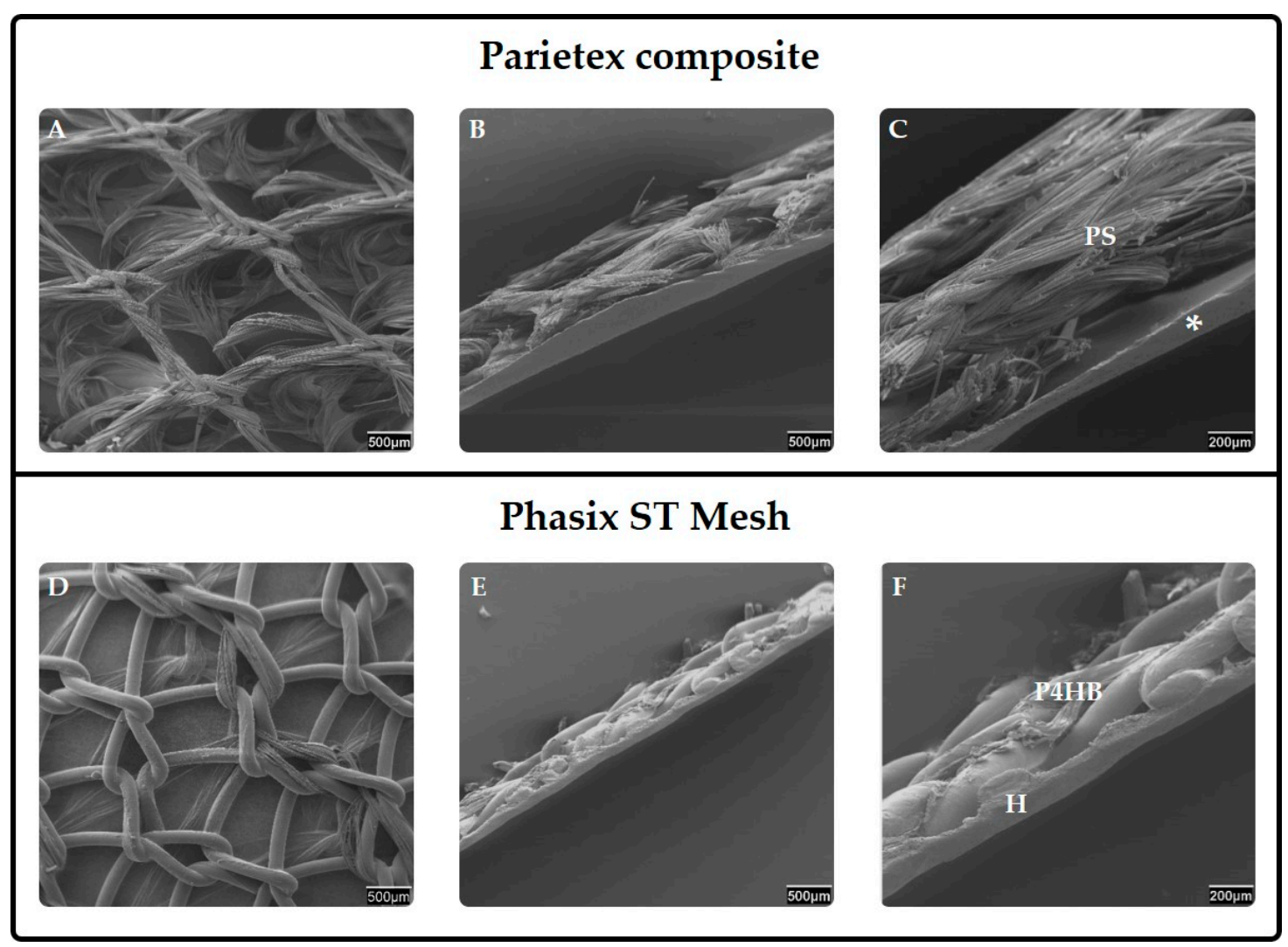

Figure 3. Composites. Scanning electron microscopy images of two different composites containing chemical barriers (Parietex ${ }^{\mathrm{TM}}$ composite and Phasix ${ }^{\mathrm{TM}}$ ST Mesh) are shown. The reticular mesh facing the abdominal wall is shown in A and D (20x magnification). A lateral view (SEM) of composites is shown in B and E (20x magnification) and C and F (50x magnification). Polyester (PS), Collagen, polyethylene glycol and glycerol layer $\left.{ }^{*}\right)$, Poly-4-hydroxybutyrate mesh (P4HB), Hydrogel barrier $(\mathrm{H})$. 


\subsubsection{Absorbable Materials}

Absorbable materials, also known as biosynthetic or bioabsorbable, like polyglactin 910 (Vicryl ${ }^{\circledR}$ ), polyglycolic acid (Dexon ${ }^{\mathrm{TM}}$ ), polyglycolic acid: Trimethylene carbonate (Bio A®) or a copolymer of glycolide lactide and trimethylene carbonate (TIGR®) (Figure 4) [93] were introduced based on the idea that full reabsorption of the material into the patients' tissue would leave no foreign material behind. When the absorbable material is introduced as a barrier, separation is achieved between the implant and viscera until the mesh becomes covered by a neoperitoneum that prevents adhesion formation [94]. These devices are supposed to act as scaffolds providing an environment for tissue in-growth and the repopulation of host cells [95] under a limited inflammatory foreign body reaction. This should diminish adhesion formation. However, some studies [96] have demonstrated that the interposition of a resorbable mesh between a PP mesh and the abdominal viscera did not reduce adhesion formation but elicited a more evident early inflammatory response. One of the major drawbacks of these materials is, in addition, the lack of long-term tensile strength that can end in recurrence [97]. For this reason, they have been indicated just for temporary use [10].

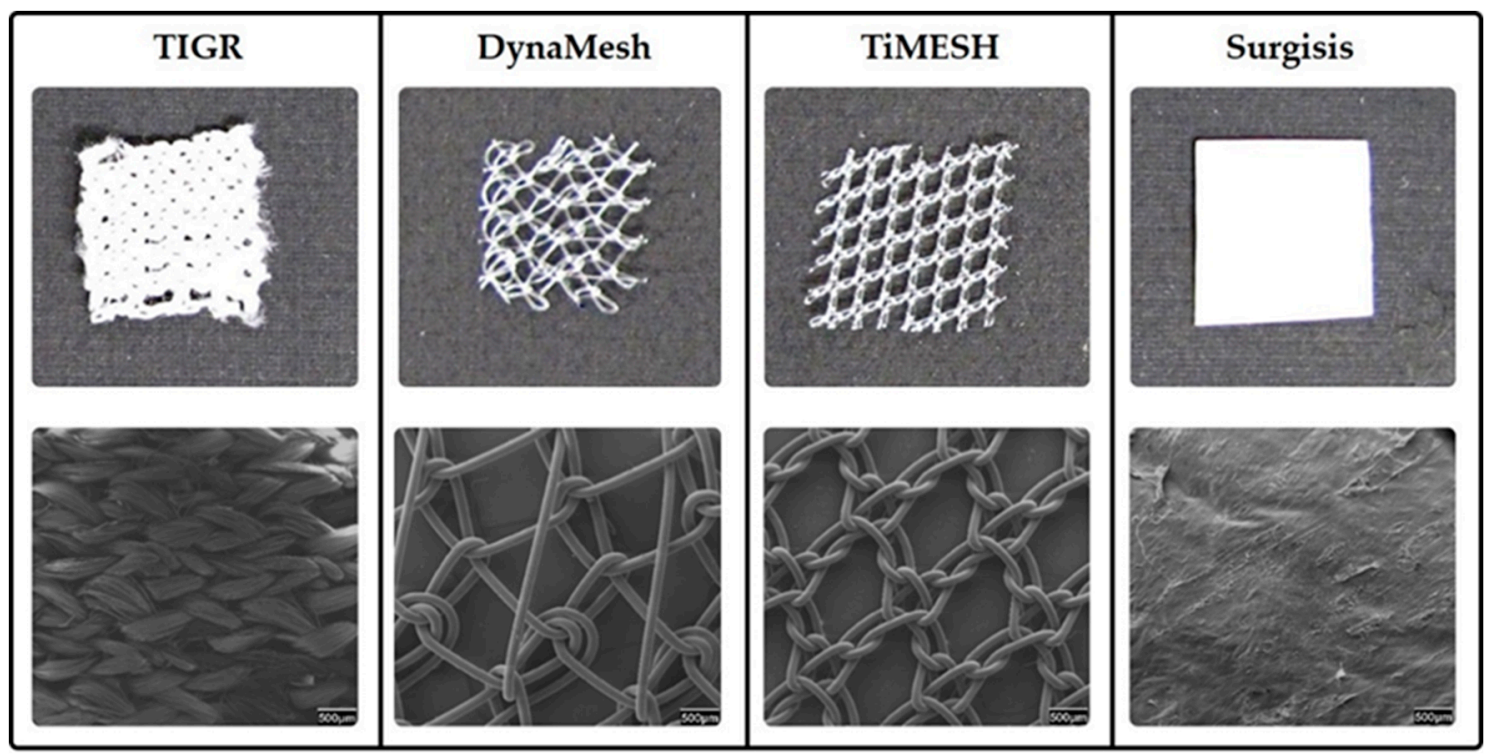

Figure 4. Top images: Macroscopic appearance of a matrix long-term absorbable mesh (TIGR®), hybrid meshes (DynaMesh ${ }^{\circledR}$ and TiMESH ${ }^{\circledR}$ ), and a biological mesh (Surgisis ${ }^{\circledR}$ ). Bottom images: Scanning electron microscopy images showing a magnified view of the structure of the meshes (20x magnification).

\subsubsection{Hybrid Meshes}

Hybrid meshes also combine different components but follow a different strategy to composites. In these meshes, the term hybrid highlights that filaments of different composition are knitted or woven together to produce a single monolayer mesh structure, or that a second element is introduced as a coating over the reticular mesh. The latter differ from the layered coated meshes in that the coating element surrounds the polymer fibers while maintaining the original reticular structure of the mesh, which does not cover the mesh pores. Hybrid meshes, despite displaying a reticular structure, include highly inert materials in the visceral side—-such as polyvinylidene fluoride (PVDF) [10] in the case of DynaMesh ${ }^{\circledR}$ — or around the filaments—-such as titanium, in the case of TiMESH®—that induce very low inflammatory response and have poor adhesiogenic potential. They can also include an absorbable material in thread form knitted together with a synthetic reticular permanent mesh [98]. However, these meshes have not either showed an acceptable performance regarding adhesion formation [99-102] since the reticular/protruding profile of the mesh provokes peritoneal damage 
even when an inert material is employed. The injury to the peritoneum is the event that triggers the coagulation cascade and the genesis of adhesions in a case of persistent inflammation.

\subsection{Biological Meshes}

Biological meshes-usually referred to as grafts or biomeshes-consist of materials derived from animal (xenograft) tissue like Surgisis ${ }^{\circledR}$ [103], Permacol ${ }^{\mathrm{TM}}[104,105]$ CollaMend ${ }^{\mathrm{TM}}$ [106], Tutomesh ${ }^{\circledR a n d}$ Strattice ${ }^{\circledR}[12,107]$ or human (allograft) tissue like Alloderm ${ }^{\mathrm{TM}}$ [87]. The first tissue-based implant composed of porcine intestinal submucosa for use in abdominal wall reconstruction (Surgisis ${ }^{\circledR}$ ) was approved in 1998 [103]. These decellularized matrices allow soft tissue to infiltrate the mesh, which eventually becomes integrated into the body by a process of remodeling. Unfortunately, this process also appears to lead to a rapid reduction in their mechanical strength, which leads to a high degree of bulging and recurrence, especially with allografts [108]. Due to this, concerns regarding this issue have restricted their use to infected environments. The use of some chemically cross-linked meshes like Permacol ${ }^{\mathrm{TM}}$ (a porcine-derived acellular dermal sheet) contributed to an increase in graft stability and durability that led to lower hernia recurrence rates while still being incorporated successfully $[12,104,105]$. However, some authors [9] concluded that cross-linking does not significantly impact the tensile strength or stiffness of the graft-tissue composites in the long term. While cross-linking these materials slows down the material absorption [109], thus increasing the mesh stability, this process can also result in a similar foreign body reaction as seen in permanent synthetic meshes [110]. Thereby, the desired effect of the so-called biocompatibility would be reduced.

Although the general consensus has traditionally advised the use of permanent synthetic materials in clean non-infected fields and the use of biologic materials in infected environments, some lightweight, macroporous permanent synthetic meshes have shown good outcomes in contaminated fields [111]. Thus, further evidence supporting the superiority of biological meshes in contaminated fields is still lacking $[13,112,113]$, with synthetic meshes proven to be superior to biologic reinforcement in some patient populations [9]. For this reason, even an antibacterial-coated biological graft has been developed for its use in contaminated fields (XenMatrix ${ }^{\mathrm{TM}} \mathrm{AB}$ Surgical Graft). These facts, together with the possibility of an immunologic response to the mesh [88], high rate of seroma formation and the higher cost for biological than for synthetic materials $[113,114]$, have led to a reduced use of this kind of meshes. Nevertheless, these biomeshes offer some advantages, such as a convenient behavior regarding the peritoneal interface. Collagen-based meshes have shown low rates of adhesion formation, similar or even lower (depending on crosslinking of the matrices) to those observed for PTFE [115].

\subsection{Cell-Coated Meshes}

The paramount importance of the interaction between the surgical mesh and the peritoneal membrane in the performance of the implant, together with the fact that the time for remesothelialization of the damaged area and the mesh surface is critical to avoid adhesion formation, supports the idea that coating the mesh with autologous cells is a very promising alternative. Both synthetic and biological meshes (e.g., Parietex ${ }^{\mathrm{TM}}$, TIGR ${ }^{\circledR}$ or Strattice ${ }^{\mathrm{TM}}$ ) have been coated with different cell populations such as fibroblasts or mesenchymal stem cells $[116,117]$. These studies focused mainly on tissue integration and found that cell-coating had a positive effect on integration with improvements in collagen deposition and ingrowth, particularly in the subcutaneous position [116]. Mesenchymal stem cells reduced mesh-induced inflammation and foreign body reaction [117], blunting the immunogenic effect. Regarding adhesions, Dolce et al. [118] showed that coating Vicryl®(polyglactin) with mesenchymal stem cells was successful in reducing the incidence of this postoperative complication, along with reduced inflammation. Also bone marrow-derived mesenchymal stem cells have shown a positive effect in reducing adhesions [119]. Recently, Cheng et al. [120] demonstrated that coating a PP mesh with adipose-derived stem cells reduced the tissue adhesion, fibrosis degree and the occurrence rate of mesh-related complications. 
Despite the promising results shown by cell-coated meshes in abdominal hernia repair, the technical difficulties and added workload that the attachment of autologous stem cells to a scaffold material implies prior to implantation, and the possibility of cells detaching prematurely must be considered. Additionally, these devices must pass strict regulatory restrictions, which can make their use in clinics is not so widespread [121]. This results in a lower use of cell-coated meshes in abdominal hernia repair.

\section{Conclusions}

The evolution of the biomaterials for abdominal wall repair has followed a logical process in which the modifications included have tried to sort out the inherent drawbacks of the current materials being used at the time. However, when comparing the performance of different commercially available meshes, the influence of just one parameter (pore size, filament distribution, composition, e.g.,) is difficult to assess since more than just one single modification is usually included in new devices and differences in the mesh structure and the knitting pattern between the meshes compared usually exist.

Furthermore, the experience has shown that the reasoned design of a mesh from a theoretical point of view not always offers the expected outcomes when experimentally tested, showing even worse results in some cases than those found for the devices being previously employed. This fact underscores the intricacy of the reparative/regenerative process in the abdominal cavity, which requires full attention and a deep understanding to obtain satisfactory results. For this reason, experimental animal models have become vital in the evaluation of abdominal meshes for hernia repair. They allow the comparison between different meshes implanted with the same surgical technique and exactly in the same anatomical position, providing essential information about the most important parameters that determine the performance of an abdominal mesh such as the degree of integration into the host tissue, the recurrence rate, proneness to encapsulation, susceptibility to infection, capacity of remesothelialization or the adhesiogenic potential.

The surgical technique itself also represents a key point in the success of an abdominal implant, which makes necessary the use of easy-handling materials and experienced personnel that produce as little damage as possible to the peritoneal interface. Despite the major progress in the field of biomaterials for abdominal wall repair, there is no ideal mesh that can perform well in every situation. Nevertheless, composites have shown positive outcomes at every interface of the implant. The combination of two specifically oriented materials-one of them designed to offer proper host tissue infiltration, and the other one providing optimal behavior at the biomaterial/visceral peritoneum interface-are composites that represent a valuable solution that can be placed at any tissue interface. While providing an appropriate tissue integration and tensile strength in abdominal wall repair, composites also avoid the most important adverse effect in intraperitoneal mesh hernia repair, the adhesion formation.

Author Contributions: Conceptualization, V.G.-G. and J.M.B.; Writing-Original Draft Preparation, V.G.-G.; Writing-Review \& Editing, V.G.-G., G.P. and J.M.B.; Visualization, V.G.-G.; Funding Acquisition, G.P. and J.M.B.

Funding: This research was supported by Grant "SAF2014-55022-P" and "SAF2017-89481-P" from the Spanish Ministry of Economy and Competitiveness.

Conflicts of Interest: The authors declare no conflict of interest.

\section{References}

1. Williams, D.F. On the mechanisms of biocompatibility. Biomaterials 2008, 29, 2941-2953. [CrossRef] [PubMed]

2. Kingsnorth, A.; LeBlanc, K. Hernias: Inguinal and incisional. Lancet 2003, 362, 1561-1571. [CrossRef]

3. Hidalgo, M.; Castellón, C.; Figueroa, J.; Eymar, J.; Moreno González, E. Complicaciones de la cirugía de las hernias. Cir. Esp. 2001, 69, 217-223. [CrossRef]

4. Bisgaard, T.; Bay-Nielsen, M.; Kehlet, H. Groin hernia repair in young males: Mesh or sutured repair? Hernia 2010, 14, 467-469. [CrossRef] [PubMed] 
5. Poulose, B.K.; Shelton, J.; Phillips, S.; Moore, D.; Nealon, W.; Penson, D.; Beck, W.; Holzman, M.D. Epidemiology and cost of ventral hernia repair: Making the case for hernia research. Hernia 2012, 16, 179-183. [CrossRef] [PubMed]

6. Luijendijk, R.W.; Hop, W.C.; van den Tol, M.P.; de Lange, D.C.; Braaksma, M.M.; IJzermans, J.N.; Boelhouwer, R.U.; de Vries, B.C.; Salu, M.K.; Wereldsma, J.C.; et al. A Comparison of Suture Repair with Mesh Repair for Incisional Hernia. N. Engl. J. Med. 2000, 343, 392-398. [CrossRef] [PubMed]

7. Petersson, P.; Montgomery, A.; Petersson, U. Wound dehiscence: Outcome comparison for sutured and mesh reconstructed patients. Hernia 2014, 18, 681-689. [CrossRef] [PubMed]

8. Burger, J.W.A.; Luijendijk, R.W.; Hop, W.C.J.; Halm, J.A.; Verdaasdonk, E.G.G.; Jeekel, J. Long-term Follow-up of a Randomized Controlled Trial of Suture Versus Mesh Repair of Incisional Hernia. Ann. Surg. 2004, CXXII, 176-183. [CrossRef]

9. Matthews, B.D.; Paton, L. Updates in Mesh and Biomaterials. Surg. Clin. N. Am. 2018, 98, 463-470. [CrossRef]

10. Todros, S.; Pavan, P.G.; Natali, A.N. Synthetic surgical meshes used in abdominal wall surgery: Part I-materials and structural conformation. J. Biomed. Mater. Res. B Appl. Biomater. 2017, 105, 689-699. [CrossRef]

11. Todros, S.; Pavan, P.G.; Pachera, P.; Natali, A.N. Synthetic surgical meshes used in abdominal wall surgery: Part II-Biomechanical aspects. J. Biomed. Mater. Res. B Appl. Biomater. 2017, 105, 892-903. [CrossRef] [PubMed]

12. Trippoli, S.; Caccese, E.; Tulli, G.; Ipponi, P.; Marinai, C.; Messori, A. Biological meshes for abdominal hernia: Lack of evidence-based recommendations for clinical use. Int. J. Surg. 2018, 52, 278-284. [CrossRef] [PubMed]

13. Guillaume, O.; Teuschl, A.H.; Gruber-Blum, S.; Fortelny, R.H.; Redl, H.; Petter-Puchner, A. Emerging Trends in Abdominal Wall Reinforcement: Bringing Bio-Functionality to Meshes. Adv. Healthc. Mater. 2015, 4, 1763-1789. [CrossRef] [PubMed]

14. Savioz, D.; Ludwig, C.; Leissing, C.; Bolle, J.F.; Bühler, L.H.; Morel, P.M. Repeated macroscopic haematuria caused by intravesical migration of a preperitoneal prosthesis. Eur. J. Surg. = Acta Chir. 1997, 163, 631-632.

15. Yamamoto, S.; Kubota, T.; Abe, T. A rare case of mechanical bowel obstruction caused by mesh plug migration. Hernia 2015, 19, 983-985. [CrossRef] [PubMed]

16. Al-Subaie, S.; Al-Haddad, M.; Al-Yaqout, W.; Al-Hajeri, M.; Claus, C. A case of a colocutaneous fistula: A rare complication of mesh migration into the sigmoid colon after open tension-free hernia repair. Int. J. Surg. Case Rep. 2015, 14, 26-29. [CrossRef] [PubMed]

17. Aziz, F.; Zaeem, M. Chronic Abdominal Pain Secondary to Mesh Erosion into Ceacum Following Incisional Hernia Repair: A Case Report and Literature Review. J. Clin. Med. Res. 2014. [CrossRef]

18. Ceci, F.; D'Amore, L.; Annesi, E.; Bambi, L.; Grimaldi, M.R.; Gossetti, F.; Negro, P. Chronic anemia due to transmural e-PTFE anti-adhesive barrier mesh migration in the small bowel after open incisional hernia repair: A case report. Int. J. Surg. Case Rep. 2018, 53, 54-57. [CrossRef]

19. Chuback, J.A.; Singh, R.S.; Sills, C.; Dick, L.S. Small bowel obstruction resulting from mesh plug migration after open inguinal hernia repair. Surgery 2000, 127, 475-476. [CrossRef]

20. Shrivastava, A.; Gupta, A.; Gupta, A.; Shrivastava, J. Erosion of small intestine with necrotising fasciitis of over lying abdominal wall after expanded poly-tetrafluoroethylene mesh implantation: A rare complication after laparoscopic incisional hernia repair. J. Minim. Access Surg. 2013, 9, 138. [CrossRef]

21. Chew, D.K.W.; Choi, L.H.; Rogers, A.M. Enterocutaneous fistula 14 years after prosthetic mesh repair of a ventral incisional hernia: A life-long risk? Surgery 2000, 127, 352-353. [CrossRef] [PubMed]

22. Morin, B.; Bonnamy, C.; Maurel, J.; Samama, G.; Gignoux, M. Fistules intestinales tardives après implantation de prothèse pariétale abdominale. Annales de Chirurgie 2001, 126, 876-880. [CrossRef]

23. Moussi, A.; Daldoul, S.; Bourguiba, B.; Othmani, D.; Zaouche, A. Gas gangrene of the abdominal wall due to late-onset enteric fistula after polyester mesh repair of an incisional hernia. Hernia 2012, 16, 215-217. [CrossRef] [PubMed]

24. Ott, V.; Groebli, Y.; Schneider, R. Late intestinal fistula formation after incisional hernia using intraperitoneal mesh. Hernia 2005, 9, 103-104. [CrossRef] [PubMed]

25. Almeida, J.A.; Franklin, M.E. Laparoscopic Repair for Inguinal Hernias: Is there a place for IPOM technique? Indications, technique and results. In Laparoscopic Ventral Hernia Repair, 1st ed.; Morales-Conde, S., Morales-Méndez, S., Eds.; Springer: Paris, France, 2003; p. 484. [CrossRef] 
26. Van Baal, J.O.A.M.; de Vijver, K.K.V.; Nieuwland, R.; van Noorden, C.J.F.; van Driel, W.J.; Sturk, A.; Kenter, G.G.; Rikkert, L.G.; Lok, C.A.R. The histophysiology and pathophysiology of the peritoneum. Tissue Cell 2017, 49, 95-105. [CrossRef] [PubMed]

27. Wang, Z.B.; Li, M.; Li, J.C. Recent Advances in the Research of Lymphatic Stomata. Anat. Rec. (Hoboken) 2010, 293, 754-761. [CrossRef] [PubMed]

28. Mutsaers, S.E. Mesothelial cells: Their structure, function and role in serosal repair. Respirology 2002, 7, 171-191. [CrossRef] [PubMed]

29. Mutsaers, S.E. The mesothelial cell. Int. J. Biochem. Cell Biol. 2004, 36, 9-16. [CrossRef]

30. Kastelein, A.W.; Vos, L.M.C.; de Jong, K.H.; van Baal, J.O.A.M.; Nieuwland, R.; van Noorden, C.J.F.; Roovers, J.P.W.R.; Lok, C.A.R. Embryology, anatomy, physiology and pathophysiology of the peritoneum and the peritoneal vasculature. Semin. Cell Dev. Biol. 2018. [CrossRef]

31. Witz, C. Composition of the extracellular matrix of the peritoneum. J. Soc. Gynecol. Investig. 2001, 8, $299-304$. [CrossRef]

32. Holmdahl, L.; Ivarsson, M. The role of cytokines, coagulation, and fibrinolysis in peritoneal tissue repair. Eur. J. Surg. 1999, 165, 1012-1019. [PubMed]

33. Aroeira, L.S.; Aguilera, A.; Sánchez-Tomero, J.A.; Bajo, M.A.; del Peso, G.; Jiménez-Heffernan, J.A.; Selgas, R.; López-Cabrera, M. Epithelial to mesenchymal transition and peritoneal membrane failure in peritoneal dialysis patients: Pathologic significance and potential therapeutic interventions. J. Am. Soc. Nephrol. 2007, 18, 2004-2013. [CrossRef]

34. Ghellai, A.M.; Stucchi, A.F.; Chegini, N.; Ma, C.; Andry, C.D.; Kaseta, J.M.; Burns, J.W.; Skinner, K.C.; Becker, J.M. Role of transforming growth factor beta-l in peritonitis-induced adhesions. J. Gastrointest. Surg. 2000, 4, 316-323. [CrossRef]

35. Fraser, D.; Wakefield, L.; Phillips, A. Independent regulation of transforming growth factor- $\beta 1$ transcription and translation by glucose and platelet-derived growth factor. Am. J. Pathol. 2002, 161, 1039-1049. [CrossRef]

36. Margetts, P.J.; Bonniaud, P.; Liu, L.; Hoff, C.M.; Holmes, C.J.; West-Mays, J.A.; Kelly, M.M. Transient overexpression of TGF- $\beta 1$ induces epithelial mesenchymal transition in the rodent peritoneum. J. Am. Soc. Nephrol. 2005, 16, 425-436. [CrossRef] [PubMed]

37. Sandoval, P.; Jiménez-Heffernan, J.A.; Guerra-Azcona, G.; Pérez-Lozano, M.L.; Rynne-Vidal, Á.; Albar-Vizcaíno, P.; Gil-Vera, F.; Martín, P.; Coronado, M.J.; Barcena, C.; Dotor, J.; et al. Mesothelial-to-mesenchymal transition in the pathogenesis of post-surgical peritoneal adhesions. J. Pathol. 2016, 239, 48-59. [CrossRef]

38. Yang, A.H.; Chen, J.Y.; Lin, J.K. Myofibroblastic conversion of mesothelial cells. Kidney Int. 2003, 63, 1530-1539. [CrossRef] [PubMed]

39. Bajo, M.A.; del Peso, G.; Teitelbaum, I. Peritoneal Membrane Preservation. Semin. Nephrol. 2017, 37, 77-92. [CrossRef] [PubMed]

40. Aroeira, L.S.; Aguilera, A.; Selgas, R.; Ramírez-Huesca, M.; Pérez-Lozano, M.L.; Cirugeda, A.; Bajo, M.A.; del Peso, G.; Sánchez-Tomero, J.A.; Jiménez-Heffernan, J.A.; et al. Mesenchymal Conversion of Mesothelial Cells as a Mechanism Responsible for High Solute Transport Rate in Peritoneal Dialysis: Role of Vascular Endothelial Growth Factor. Am. J. Kidney Dis. 2005, 46, 938-948. [CrossRef]

41. Capobianco, A.; Cottone, L.; Monno, A.; Manfredi, A.A.; Rovere-Querini, P. The peritoneum: Healing, immunity, and diseases. J. Pathol. 2017, 243, 137-147. [CrossRef]

42. Vita, G.D.; Patti, R.; D’Agostino, P.; Caruso, G.; Arcara, M.; Buscemi, S.; Bonventre, S.; Ferlazzo, V.; Arcoleo, F.; Cillari, E. Cytokines and growth factors in wound drainage fluid from patients undergoing incisional hernia repair. Wound Repair Regen. 2006, 14, 259-264. [CrossRef] [PubMed]

43. Mazzaferro, D.; Song, P.; Massand, S.; Jaiswal, R.; Pu, L.; Mirmanesh, M. The Omental Free Flap-A Review of Usage and Physiology. J. Reconstr. Microsurg. 2018, 34, 151-169. [CrossRef]

44. Weibel, M.A.; Majno, G. Peritoneal adhesions and their relation to abdominal surgery. Am. J. Surg. 1973, 126, 345-353. [CrossRef]

45. Gómez-Gil, V.; García-Honduvilla, N.; Pascual, G.; Rodríguez, M.; Buján, J.; Bellón, J.M. Peritoneal adhesion formation and reformation tracked by sequential laparoscopy: Optimizing the time point for adhesiolysis. Surgery 2010, 147, 378-391. [CrossRef] [PubMed]

46. Keating, J.H.; Melidone, R.; Garcia-Polite, F. Preclinical Evaluation of Mesh Implants: The Pathologist's Perspective. Toxicol. Pathol. 2018, 20. [CrossRef] 
47. Rangel-Moreno, J.; Moyron-Quiroz, J.E.; Carragher, D.M.; Kusser, K.; Hartson, L.; Moquin, A.; Randall, T.D. Omental Milky Spots Develop in the Absence of Lymphoid Tissue-Inducer Cells and Support B and T Cell Responses to Peritoneal Antigens. Immunity 2009, 30, 731-743. [CrossRef] [PubMed]

48. Mebius, R.E. Lymphoid Organs for Peritoneal Cavity Immune Response: Milky Spots. Immunity 2009, 30, 670-672. [CrossRef] [PubMed]

49. Gómez-Gil, V.; Pascual, G.; Pérez-Köhler, B.; Cifuentes, A.; Buján, J.; Bellón, J.M. Involvement of transforming growth factor- $\beta 3$ and betaglycan in the cytoarchitecture of postoperative omental adhesions. J. Surg. Res. 2014, 187, 699-711. [CrossRef] [PubMed]

50. Isaza-Restrepo, A.; Martin-Saavedra, J.S.; Velez-Leal, J.L.; Vargas-Barato, F.; Riveros-Dueñas, R. The Peritoneum: Beyond the Tissue-A Review. Front. Physiol. 2018, 9. [CrossRef]

51. Junge, K.; Binnebösel, M.; von Trotha, K.T.; Rosch, R.; Klinge, U.; Neumann, U.P.; Jansen, P.L. Mesh biocompatibility: Effects of cellular inflammation and tissue remodelling. Langenbecks Arch. Surg. 2012, 397, 255-270. [CrossRef]

52. Mutsaers, S.E.; Prêle, C.M.A.; Pengelly, S.; Herrick, S.E. Mesothelial cells and peritoneal homeostasis. Fertil. Steril. 2016, 106, 1018-1024. [CrossRef] [PubMed]

53. Matthews, B.D.; Mostafa, G.; Carbonell, A.M.; Joels, C.S.; Kercher, K.W.; Austin, C.; Norton, H.J.; Heniford, B.T. Evaluation of adhesion formation and host tissue response to intra-abdominal polytetrafluoroethylene mesh and composite prosthetic mesh. J. Surg. Res. 2005, 123, 227-234. [CrossRef] [PubMed]

54. Stommel, M.W.J.; Strik, C.; ten Broek, R.P.G.; de Wilt, J.H.W.; van Goor, H. Impact of Adhesiolysis on Outcome of Colorectal Surgery. Dig. Surg. 2016, 33, 83-93. [CrossRef] [PubMed]

55. Vrijland, W.W.; Jeekel, J.; van Geldorp, H.J.; Swank, D.J.; Bonjer, H.J. Abdominal adhesions: Intestinal obstruction, pain, and infertility. Surg. Endosc. 2003, 17, 1017-1022. [CrossRef] [PubMed]

56. Diamond, M.P.; Freeman, M.L. Clinical implications of postsurgical adhesions. Hum. Reprod. Update 2001, 7, 567-576. [CrossRef] [PubMed]

57. Menzies, D.; Ellis, H. Intestinal obstruction from adhesions-How big is the problem? Ann. R. Coll. Surg. Engl. 1990, 72, 60-63. [PubMed]

58. Menzies, D. Postoperative adhesions: Their treatment and relevance in clinical practice. Ann. R. Coll. Surg. Engl. 1993, 75, 147-153.

59. Moris, D.; Chakedis, J.; Rahnemai-Azar, A.A.; Wilson, A.; Hennessy, M.M.; Athanasiou, A.; Beal, E.W.; Argyrou, C.; Felekouras, E.; Pawlik, T.M. Postoperative Abdominal Adhesions: Clinical Significance and Advances in Prevention and Management. J. Gastrointest. Surg. 2017, 21, 1713-1722. [CrossRef]

60. Turza, K.C.; Butler, C.E. Adhesions and Meshes. Plast. Reconstr. Surg. 2012, 130, 206S-213S. [CrossRef]

61. Ergul, E.; Korukluoglu, B. Peritoneal adhesions: Facing the enemy. Int. J. Surg. 2008, 6, 253-260. [CrossRef]

62. Maciver, A.H.; McCall, M.; Shapiro, A.M.J. Intra-abdominal adhesions: Cellular mechanisms and strategies for prevention. Int. J. Surg. 2011, 9, 589-594. [CrossRef] [PubMed]

63. Bellón, J.M.; Contreras, L.A.; Buján, J.; Jurado, F. Effect of phosphatidylcholine on the process of peritoneal adhesion following implantation of a polypropylene mesh prosthesis. Biomaterials 1996, 17, 1369-1372. [CrossRef]

64. Diamond, M.P.; Daniell, J.F.; Feste, J.; Surrey, M.W.; McLaughlin, D.S.; Friedman, S.; Vaughn, W.K.; Martin, D.C. Adhesion reformation and de novo adhesion formation after reproductive pelvic surgery. Fertil. Steril. 1987, 47, 864-866. [CrossRef]

65. Zuhlke, H.V.; Lorenz, E.M.; Straub, E.M.; Savvas, V. Pathophysiology and Classification of Adhesions. In Langenbecks Archiv für Chirurgie Supplement II, Verhandlungen der Deutschen Gesellschaft für Chirurgie Deutsche Gesellschaft für Chirurgie Kongress; Springer: Berlin, Germany, 1990; Volume 190, pp. 1009-1016. [CrossRef]

66. Coccolini, F.; Ansaloni, L.; Manfredi, R.; Campanati, L.; Poiasina, E.; Bertoli, P.; Capponi, M.G.; Sartelli, M.; Saverio, S.D.; Cucchi, M.; et al. Peritoneal adhesion index (PAI): Proposal of a score for the "ignored iceberg" of medicine and surgery. World J. Emerg. Surg. 2013, 8, 6. [CrossRef] [PubMed]

67. Rossi, L.F.; Trindade, M.R.M.; D’Acampora, A.J.; Meurer, L. Peritoneal adhesions type I, III and total collagen on polypropylene and coated polypropylene meshes: Experimental study in rats. Arq. Bras. Cir. Dig. 2017, 30, 77-82. [CrossRef] [PubMed]

68. Deeken, C.R.; Lake, S.P. Mechanical properties of the abdominal wall and biomaterials utilized for hernia repair. J. Mech. Behav. Biomed. Mater. 2017, 74, 411-427. [CrossRef] [PubMed] 
69. Baylón, K.; Rodríguez-Camarillo, P.; Elías-Zúñiga, A.; Díaz-Elizondo, J.A.; Gilkerson, R.; Lozano, K. Past, Present and Future of Surgical Meshes: A Review. Membranes 2017, 7. [CrossRef]

70. Usher, F.; Fries, J.; Ochsner, J.; Tuttle, L.D. Marlex mesh, a new plastic mesh for replacing tissue defects: II. Clinical studies. AMA Arch. Surg. 1959, 78, 138-145. [CrossRef]

71. Usher, F.C. Hernia repair with knitted polypropylene mesh. Surg. Gynecol. Obstet. 1963, 117, $239-240$.

72. Stoppa, R.; Petit, J.; Henry, X. Unsutured Dacron prosthesis in groin hernias. Int. Surg. 1975, 60, 411-412.

73. Brown, R.H.; Subramanian, A.; Hwang, C.S.; Chang, S.; Awad, S.S. Comparison of infectious complications with synthetic mesh in ventral hernia repair. Am. J. Surg. 2013, 205, 182-187. [CrossRef] [PubMed]

74. Klinge, U.; Klosterhalfen, B.; Müller, M.; Öttinger, A.P.; Schumpelick, V. Shrinking of polypropylene mesh in vivo: An experimental study in dogs. Eur. J. Surg. 1998, 164, 965-969. [CrossRef] [PubMed]

75. Bauer, JJ.; Salky, BA.; Gelernt, IM.; Kreel, I. Repair of Large Abdominal Wall Defects with Expanded Polytetrafluoroethylene (PTFE). Ann. Surg. 1987, 206, 765-769. [CrossRef]

76. Read, R.C. Milestones in the history of hernia surgery: Prosthetic repair. Hernia 2004, 8, 8-14. [CrossRef] [PubMed]

77. Bellón, J.M. Mallas y cirugía. ¿Cuáles y cuándo? Cir. Esp. 2003, 74, 1-3. [CrossRef]

78. Byrd, J.F.; Agee, N.; Nguyen, P.H.; Heath, J.J.; Lau, K.N.; Mckillop, I.H.; Sindram, D.; Martinie, J.B.; Iannitti, D.A. Evaluation of Composite Mesh for Ventral Hernia Repair. JSLS J. Soc. Laparoendosc. Surg. Soc. Laparoendosc. Surg. 2011, 15, 298-304. [CrossRef] [PubMed]

79. Diaz, J.J.; Gray, B.; Dobson, J.; Grogan, E.; May, A.; Miller, R.; Guy, J.; O’Neill, P.; Morris, J.J. Repair of giant abdominal hernias: Does the type of prosthesis matter? Am. Surg. 2004, 70, 396-402.

80. Bellón, J.M.; Jurado, F.; García-Honduvilla, N.; López, R.; Carrera-San Martín, A.; Buján, J. The structure of a biomaterial rather than its chemical composition modulates the repair process at the peritoneal level. Am. J. Surg. 2002, 184, 154-159. [CrossRef]

81. Eriksen, J.R.; Gögenur, I.; Rosenberg, J. Choice of mesh for laparoscopic ventral hernia repair. Hernia 2007, 11, 481-492. [CrossRef]

82. Deeken, C.R.; Faucher, K.M.; Matthews, B.D. A review of the composition, characteristics, and effectiveness of barrier mesh prostheses utilized for laparoscopic ventral hernia repair. Surg. Endosc. 2012, 26, 566-575. [CrossRef]

83. Koehler, R.H.; Begos, D.; Berger, D.; Carey, S.; LeBlanc, K.; Park, A.; Ramshaw, B.; Smoot, R.; Voeller, G. Minimal adhesions to ePTFE mesh after laparoscopic ventral incisional hernia repair: Reoperative findings in 65 cases. Zentralblatt für Chirurgie 2003, 128, 625-630. [CrossRef] [PubMed]

84. Wassenaar, E.B.; Schoenmaeckers, E.J.P.; Raymakers, J.T.F.J.; Rakic, S. Subsequent abdominal surgery after laparoscopic ventral and incisional hernia repair with an expanded polytetrafluoroethylene mesh: A single institution experience with 72 reoperations. Hernia 2010, 14, 137-142. [CrossRef] [PubMed]

85. Bellón, J.M.; Serrano, N.; Rodríguez, M.; García-Honduvilla, N.; Pascual, G.; Buján, J. Composite prostheses used to repair abdominal wall defects: Physical or chemical adhesion barriers? J. Biomed. Mater. Res. B Appl. Biomater. 2005, 74B, 718-724. [CrossRef] [PubMed]

86. Schreinemacher, M.H.F.; Emans, P.J.; Gijbels, M.J.J.; Greve, J.W.M.; Beets, G.L.; Bouvy, N.D. Degradation of mesh coatings and intraperitoneal adhesion formation in an experimental model. Br. J. Surg. 2009, 96, 305-313. [CrossRef] [PubMed]

87. Robinson, T.N.; Clarke, J.H.; Schoen, J.; Walsh, M.D. Major mesh-related complications following hernia repair. Surg. Endosc. 2005, 19, 1556-1560. [CrossRef] [PubMed]

88. Greenawalt, K.E.; Butler, T.J.; Rowe, E.A.; Finneral, A.C.; Garlick, D.S.; Burns, J.W. Evaluation of Sepramesh Biosurgical Composite in a Rabbit Hernia Repair Model. J. Surg. Res. 2000, 94, 92-98. [CrossRef] [PubMed]

89. Bohmer, R.; Byrne, P.; Maddern, G. A peeling mesh. Hernia 2002, 6, 86-87. [CrossRef]

90. Konerding, M.A.; Chantereau, P.; Delventhal, V.; Holste, J.L.; Ackermann, M. Biomechanical and histological evaluation of abdominal wall compliance with intraperitoneal onlay mesh implants in rabbits: A comparison of six different state-of-the-art meshes. Med. Eng. Phys. 2012, 34, 806-816. [CrossRef]

91. Judge, T.W.; Parker, D.M.; Dinsmore, R.C. Abdominal Wall Hernia Repair: A Comparison of Sepramesh and Parietex Composite Mesh in a Rabbit Hernia Model. J. Am. Coll. Surg. 2007, 204, 276-281. [CrossRef]

92. Bittner, J.G.; El-Hayek, K.; Strong, A.T.; LaPinska, M.P.; Yoo, J.S.; Pauli, E.M.; Kroh, M. First human use of hybrid synthetic/biologic mesh in ventral hernia repair: A multicenter trial. Surg. Endosc. 2018, 32, 1123-1130. [CrossRef] 
93. Abid, S.; El-Hayek, K. Which mesh or graft? Prosthetic devices for abdominal wall reconstruction. Br. J. Hosp. Med. (Lond.) 2016, 77, 157-161. [CrossRef] [PubMed]

94. Bellón, J.M.; Rodríguez, M.; García-Honduvilla, N.; Pascual, G.; Gómez Gil, V.; Buján, J. Peritoneal Effects of Prosthetic Meshes Used to Repair Abdominal Wall Defects: Monitoring Adhesions by Sequential Laparoscopy. J. Laparoendosc. Adv. Surg. Tech. A 2007, 17, 160-166. [CrossRef] [PubMed]

95. Ruiz-Jasbon, F.; Norrby, J.; Ivarsson, M.L.; Björck, S. Inguinal hernia repair using a synthetic long-term resorbable mesh: Results from a 3-year prospective safety and performance study. Hernia 2014, 18, 723-730. [CrossRef] [PubMed]

96. De Vries Reilingh, T.S.; van Goor, H.; Koppe, M.J.; Bodegom, M.E.; Hendriks, T.; Bleichrodt, R.P. Interposition of Polyglactin Mesh Does Not Prevent Adhesion Formation Between Viscera and Polypropylene Mesh. J. Surg. Res. 2007, 140, 27-30. [CrossRef] [PubMed]

97. Tyrell, J.; Silberman, H.; Chandrasoma, P.; Niland, J.; Shull, J. Absorbable Versus Permanent Mesh in Abdominal Operations. Surg. Gynecol. Obstet. 1989, 168, 227-232. [PubMed]

98. Junge, K.; Rosch, R.; Krones, C.J.; Klinge, U.; Mertens, P.R.; Lynen, P.; Schumpelick, V.; Klosterhalfen, B. Influence of polyglecaprone 25 (Monocryl) supplementation on the biocompatibility of a polypropylene mesh for hernia repair. Hernia 2005, 9, 212-217. [CrossRef] [PubMed]

99. Fortelny, R.H.; Petter-Puchner, A.H.; Glaser, K.S.; Offner, F.; Benesch, T.; Rohr, M. Adverse effects of polyvinylidene fluoride-coated polypropylene mesh used for laparoscopic intraperitoneal onlay repair of incisional hernia. Br. J. Surg. 2010, 97, 1140-1145. [CrossRef]

100. Jamry, A.; Jałyński, M.; Piskorz, L.; Brocki, M. Assessment of adhesion formation after laparoscopic intraperitoneal implantation of Dynamesh IPOM mesh. Arch. Med. Sci. 2013, 9, 487-492. [CrossRef]

101. D'Amore, L.; Ceci, F.; Mattia, S.; Fabbi, M.; Negro, P.; Gossetti, F. Adhesion prevention in ventral hernia repair: An experimental study comparing three lightweight porous meshes recommended for intraperitoneal use. Hernia 2017, 21, 115-123. [CrossRef]

102. Burger, J.W.; Halm, J.A.; Wijsmuller, A.R.; ten Raa, S.; Jeekel, J. Evaluation of new prosthetic meshes for ventral hernia repair. Surg. Endosc. 2006, 20, 1320-1325. [CrossRef]

103. Franklin, M.; Gonzalez, J.; Michaelson, R.; Glass, J.; Chock, D. Preliminary experience with new bioactive prosthetic material for repair of hernias in infected fields. Hernia 2002, 6, 171-174. [CrossRef] [PubMed]

104. Chand, B.; Indeck, M.; Needleman, B.; Finnegan, M.; Van Sickle, KR.; Ystgaard, B.; Gossetti, F.; Pullan, R.D.; Giordano, P.; McKinley, A. A retrospective study evaluating the use of Permacol ${ }^{\mathrm{TM}}$ surgical implant in incisional and ventral hernia repair. Int. J. Surg. 2014, 12, 296-303. [CrossRef] [PubMed]

105. Pavan, P.G.; Pachera, P.; Todros, S. Mechanical characterization of animal derived grafts for surgical implantation. J. Mech. Med. Biol. 2016, 16. [CrossRef]

106. Chavarriaga, L.F.; Lin, E.; Losken, A.; Cook, M.W.; Jeansonne, L.O.; White, B.C.; Sweeney, J.F.; Galloway, J.R.; Davis, S.S., Jr. Management of complex abdominal wall defects using acellular porcine dermal collagen. Am. Surg. 2010, 76, 96-100. [PubMed]

107. Pascual, G.; Pérez-Köhler, B.; Rodríguez, M.; Sotomayor, S.; Bellón, J.M. Postimplantation host tissue response and biodegradation of biologic versus polymer meshes implanted in an intraperitoneal position. Surg. Endoc. 2014, 28, 559-569. [CrossRef] [PubMed]

108. Beale, E.W.; Hoxworth, R.E.; Livingston, E.H.; Trussler, A.P. The role of biologic mesh in abdominal wall reconstruction: A systematic review of the current literature. Am. J. Surg. 2012, 204, 510-517. [CrossRef] [PubMed]

109. Dunn, R.M. Cross-Linking in Biomaterials. Plast. Reconstr. Surg. 2012, 130, 18S-26S. [CrossRef] [PubMed]

110. Novitsky, Y. Biology of Biological Meshes Used in Hernia Repair. Surg. Clin. N. Am. 2013, 93, 1211-1215. [CrossRef] [PubMed]

111. Carbonell, A.M.; Criss, C.N.; Cobb, W.S.; Novitsky, Y.W.; Rosen, M.J. Outcomes of Synthetic Mesh in Contaminated Ventral Hernia Repairs. J. Am. Coll. Surg. 2013, 217, 991-998. [CrossRef] [PubMed]

112. Bellows, C.F.; Smith, A.; Malsbury, J.; Helton, W.S. Repair of incisional hernias with biological prosthesis: A systematic review of current evidence. Am. J. Surg. 2013, 205, 85-101. [CrossRef] [PubMed]

113. Slater, N.J.; van der Kolk, M.; Hendriks, T.; van Goor, H.; Bleichrodt, R.P. Biologic grafts for ventral hernia repair: A systematic review. Am. J. Surg. 2013, 205, 220-230. [CrossRef] [PubMed] 
114. Rosen, M.J.; DeNoto, G.; Itani, K.M.F.; Butler, C.; Vargo, D.; Smiell, J.; Rutan, R. Evaluation of surgical outcomes of retro-rectus versus intraperitoneal reinforcement with bio-prosthetic mesh in the repair of contaminated ventral hernias. Hernia 2013, 17, 31-35. [CrossRef] [PubMed]

115. Bellón, J.M.; Rodríguez, M.; Gómez-Gil, V.; Sotomayor, S.; Buján, J.; Pascual, G. Postimplant intraperitoneal behavior of collagen-based meshes followed by laparoscopy. Surg. Endosc. 2012, 26, 27-35. [CrossRef] [PubMed]

116. Majumder, A.; Gao, Y.; Sadava, E.E.; Anderson, J.M.; Novitsky, Y.W. Cell-coating affects tissue integration of synthetic and biologic meshes: Comparative analysis of the onlay and underlay mesh positioning in rats. Surg. Endosc. 2016, 30, 4445-4453. [CrossRef] [PubMed]

117. Gao, Y.; Krpata, D.M.; Criss, C.N.; Liu, L.; Posielski, N.; Rosen, M.J.; Novitsky, Y.W. Effects of mesenchymal stem cell and fibroblast coating on immunogenic potential of prosthetic meshes in vitro. Surg. Endosc. 2014, 28, 2357-2367. [CrossRef] [PubMed]

118. Dolce, C.J.; Stefanidis, D.; Keller, J.E.; Walters, K.C.; Newcomb, W.L.; Heath, J.J.; Norton, H.J.; Lincourt, A.E.; Kercher, K.W.; Heniford, B.T. Pushing the envelope in biomaterial research: Initial results of prosthetic coating with stem cells in a rat model. Surg. Endosc. 2010, 24, 2687-2693. [CrossRef] [PubMed]

119. Zhao, Y.; Zhang, Z.; Wang, J.; Yin, P.; Zhou, J.; Zhen, M.; Cui, W.; Xu, G.; Yang, D.; Liu, Z. Abdominal Hernia Repair with a Decellularized Dermal Scaffold Seeded with Autologous Bone Marrow-Derived Mesenchymal Stem Cells. Artif. Organs 2012, 36, 247-255. [CrossRef]

120. Cheng, H.; Zhang, Y.; Zhang, B.; Cheng, J.; Wang, W.; Tang, X.; Teng, P.; Li, Y. Biocompatibility of polypropylene mesh scaffold with adipose-derived stem cells. Exp. Ther. Med. 2017, 13, 2922-2926. [CrossRef]

121. Petter-Puchner, A.H.; Fortelny, R.H.; Gruber-Blum, S.; Redl, H.; Dietz, U. The future of stem cell therapy in hernia and abdominal wall repair. Hernia 2015, 19, 25-31. [CrossRef]

(C) 2019 by the authors. Licensee MDPI, Basel, Switzerland. This article is an open access article distributed under the terms and conditions of the Creative Commons Attribution (CC BY) license (http:/ / creativecommons.org/licenses/by/4.0/). 